\title{
Sacrifice among the Lodagaa and elsewhere
}

A comparative comment on implicit questions and explicit rejections

Sacrifice chez les Lodagaa et ailleurs: Un commentaire comparatif sur des questions implicites et des refus explicites

Jack Goody

\section{OpenEdition}

\section{Journals}

Electronic version

URL: http://journals.openedition.org/span/485

DOI: $10.4000 /$ span. 485

ISSN: 2268-1558

Publisher

École pratique des hautes études. Sciences humaines

\section{Printed version}

Date of publication: 30 May 1981

Number of pages: 9-22

ISSN: 0294-7080

\section{Electronic reference}

Jack Goody, "Sacrifice among the Lodagaa and elsewhere », Systèmes de pensée en Afrique noire [Online], 5 | 1981, Online since 11 June 2013, connection on 01 May 2019. URL : http:// journals.openedition.org/span/485; DOI : 10.4000/span.485 
S A C R I F I C E A WH E R E : A C O M P A R A T I V E C O M M E N T O N I M P L I C I T Q U U E S S T I O par Jack Goody

My initia1 interest in sacrifice among the LoDagaa, in a work entitled Death, Property and the Ancestors (1962), was in the specific relationships, kin relations, berween man and god, between donor and recipient (and sacrificer as a third party) which sacrifices to the ancestors involve. This interest paralleled the contemporary concern of many other anthropologists with the phenomenon of witchcraft, in the tripartite relationship between victim, witch (accused) and accuser. We were primarily interested in what such "ritual" activities could tell us about man-to-man relations, about social relations in that sense and only secondarily in the network of beliefs.

I do not want to discuss the validity of this approach, except to say that the question of the relations between the actors is of obvious significance to offerings, as Robertson Smith perceived (though it applies mainly to sacrifice to the ancestors) ; and it clearly does not inhibit any other form of analysis, i.e. a study of the beliefs "in themselves". One reason for this importance, then and now, is that such an approach offers an opportunity of bringing together ( $I$ won't say integrating) certain insights of Freud and Marx, of seeing the relations among men over poverty, office and sex as being fraught with conflict, of using these aspects of religious institutions to determine the nature of the conflicts (as well as the solidarities) in the critical relations of the society concerned, and of analysing the connections between the social and personality systems ( to a lesser extent the cultural) not only within a single society but also in a comparative context. It is a form of analysis associated with 
the nemes of Malinowski, Fortes, Gluckman and Nadel, among others ; if it has been neglected in recent years, it is anthropology's loss.

In examining the ancestral sacrifices among the LoDagaa I argued (on the basis of comparing two different groups) that sacrifice was not a gift, even though I spoke of givers and receivers. The difference between the groups I studied was explained by differences in the control over property. In one society (the LoDagaa or "Dagari"), the matriclans were "corporate" in a particular sense ; it was members of such clans who were the holders, and the inheritors, of movable property, above all of the objects (or subjects) of blood sacrifice, that is, domestic anima1s. In this kind of sacrifice, a man has to render to the ancestors that which he owes, that is to say, the goods that he has inherited, or that he has acquired through their help and the help of what they have left behind. Hence, the sacrifice is not a gift but the return of a debt; one is giving the ancestors their due.

This notion of sacrifice seems to me correct for sacrifices to the ancestors. But there are other modalities of sacrifice among the LoDagaa which are somewhat different and which demand other explanations. What I offered was certainly no "theory of sacrifice", an undertaking that seems to me as impossible as a "theory of gift". One cannot justify a single vision or explanation of "sacrifice" even in one society for reasons that seem sufficiently obvious even if rarely understood.

It goes without saying that in my discussion of sacrifice one must not confuse the concepts of the observer with that of the actors. For the LoDagaa, and in my opinion for many other people in the region, the relations between the two are somewhat tenuous, which makes it difficult to discuss sacrifice as a système de pensée, especially if one has been more concerned with the interpenetration of "thought" and "acts" in a system of action.

We can look at sacrifice as a system of acts or as a system of ideas, although these are not of course alternatives; ideas in a sense are acts of behaviour and both interlock to form a system of action. A stress upon the acts is justifiable for two reasons. Firstly, acts are more generally standardised than ideas (thoughts about the process of sacrifice seem to be much more variable then the acts themselves). Secondly, one cannot be altogether satisfied at the way 
Sacrifice among the LoDagaa and elsewhere : a comparative comment 11

anthropologists usually specify ideas, not only because they deal with few informants whereas the likelihood of variability makes it necessary to deal with more, not less, than for acts (which usually involve a plurality of participants), but also because they are less likely to gather correct information with their ears than with their eyes.

For these reasons, the discussion of ideas is more likely to reflect the prejudices, personal and cultural, of the observer. One may wish to describe this approach as smacking of empiricism ; it might also be seen as displaying proper scholarly caution.

We can also look at sacrifice from the actor's and the observer's standpoints. The first must of course be the basis of the second, and is important in its own right. But to remain at the ethno-methodological level, or even to present a more "coherent" (i.e. constructed) cultural account, is not (for me) the end game. It is the sociological and particularly the comparative sociological explanation which I find most interesting; this does not mean I want to explain away religious institutions but that I want to uncover any systematic links with other aspects of socio-cultural systems, at whatever level.

In the discussion of observers, there are two general usages of "sacrifice", one wider (inclusive), the other narrower (exclusive) :

The semantic field of "sacrifice" (observer term)

A. ritual, ceremony, act of man-god communication involving

B. the offering, especially the slaughter, of a domestic animal. What are equivalent concepts at the actor level ?

The nearest equivalent of the word "sacrifice" in LoDagaa is maala bagr (or bøQr), same word as in Bagre, "the Myth of the Bagre", the name of a secret association, and the same as the Tallensi concept of bagr (Fortes 1949), though in the latter case the term refers rather to the altar at the point of contact, to avoid the overstretched word "communication". I have translated the term bagr, not altogether satisfactorily, as "mystical trouble". A sacrifice is in effect always preceded by the act of divination (the diviner is known as the bagbuura, he who seeks the bagr), which involves the manipulation of a set of cowries and a series of tokens and which always (or virtually always) points the way to a sacrifice at an altar. The English word "token", 
in one of its senses, is very precisely what I mean here, because the material objects are sometimes visual equivalents, smaller versions, almost "toys", of the objects or shrines themselves; in other cases they "stand for" the denota in a very precise way, and sometimes less precise $1 \mathrm{y}$.

Clearly people do not go to a diviner "by heart", as West African English has it (i.e. for nothing), since the outcome always involves a loss, usually the loss of an animal. They go because they are suffering from a misfortune, or anticipate one, and because such "mystical trouble" is dealt with by recourse to a diviner who in turn usually tells the subject to approach a certain shrine and perform a certain sacrifice (in the more restricted sense of the word). This procedure is known as maale bagr, to repair the mystical wrong. I use the word "mystical" here simply to point to the fact that the solution is deemed to be through an altar, the locus of contacting a type of agency (or divinity) that I call divine or supernatural, for the sake of convenience and communication.

So sacrifice (in the inclusive sense) usually involves :

\section{The sacrificial sequence}

1. a condition of misfortune on the part of one or more people who decide upon :

2. consultation of diviner

3. who points to an altar/divinity (never to God who has no altar, though this situation is not entirely static (Goody 1977),

4. leading to an offering, a sacrifice in the narrower sense, involving

assembly at the altar

gesture

prayer a. greeting

b. content

c. confirmation

offering

disposat of the offering

dispersal of participants

Thus the sacrifice, either the immolation of a domestic animal or 
Sacrifice among the LoDagaa and elsewhere : a comparative comment 13

the offering of cultivated plants, is only part of totality, which is the rite or ceremony. For the LoDagaa, the other phases carry much weight, even though the characteristic act is the communion between man and god at the altar. There is the gathering of the participants and more especially the principals (the donors and the intermediaries), especially the sacrificer, as well as the object of sacrifice.

The approach to the altar is followed by the performance of acts of address, gestural (involving the body), manipulative (with objects), but above all verbal. Since there is some danger of the gesture being swamped by the paroze (especially in the discussion of sacrifice), it is worth commenting that even if one is enquiring into intention, motive or goal, or into ideas or systems of thought, one of these elements is no less sound an index than any other; indeed the different channels may carry contradictory messages, as one writes a letter of apology but acts defiantly or defensively towards the rest of the world.

"Confirmation" refers to the attempt to make certain that the diviner's diagnosis of the cause of misfortune is correct ; otherwise an offering is made for nothing. Often the form that confirmation takes is the slaughter of a chicken, whose posture, favourable (dying on its back) or unfavourable (dying on its belly), is held to be an answer to the question posed. It is a form of divination interior to the sacrificial sequence.

The offering is the sacrificing of the animal, the handing over of the cooked foods, the donation of the produce of the fields, the libation of beer or the pouring of water. Among the LoDagaa, the sacrificial animal is a chicken, guinea fowl, goat, sheep, dog or cow, never a horse or donkey. The offering is followed by the disposal of the edibles among men and gods, the drinking of beer, the butchering of the animal, the cooking there and then of certain portions of the meat, the formal allocation of the remainder to specified individuals and categories, which precedes the final dispersal of the participants, bearing their allotted portions of the sacrifice.

It should also be said that the word bagr (in the context of maala bagr) can be used of regular offerings to the gods, for example at the time of harvest when offerings of first fruits are made to the shrines; blood sacrifices are often made at the time of bagmaal daa, the Beer of Sacrifice, though the offerings are more in the nature of a 
thank-you than a request. More characteristically the phrase bagr ben be means "a sacrifice needs to be made" because of some trouble.

Sacrifice in the wider sense (A) is an aspect of man-god communication, if I may use the term god in a loose general sense for spiritual agencies, including the ancestors, that is, men made gods. There are clearly similarities between the acts of communication between the living and the dead, and hence presumably the ideas (i.e. thoughts, ideology) of the actors concerning such acts. These acts are not of course formally equivalent in every detail. But the elements of sacrifice, the coming towards, the crouching, the prayer, the offering, the dispersal, are all acts of an inferior towards a superior.

Clearly the actual shape of the act of communication will vary depending on the nature of the recipient, the relation between donor and recipient (giver and receiver) and the content of the specific transaction. As far as ancestor worship is concerned, there are a variety of possible subjects (receivers) and my own earlier study was an attempt to link the donor-recipient relation (D-R) with other aspects of the social system, namely with the holder-heir relation (Ho-He).

One of the most important aspects of sacrifice is the negative case, whom one does not communicate with. Among the LoDagaa, as elsewhere in West Africa, it is the High God (naamin) who falls into this latter category. To Him one makes no sort of offering nor any verbal petition or prayer. To this point we will return.

Among the LoDagaa, then, the phrase maala bagr is the rough equivalent of sacrifice $A$, the inclusive usage, indicating man-god communication of this set type. Sacrifice in this sense appears to be universal of religious systems; it is their characteristic mode of communication (and as such it does not require much by way of explanation).

But there is also the more specific sense in which the term sacrifice is used, referring specifically

a) to offering some material object, usually edible, usually food, drink or flesh,

b) or more specifically the formal slaughter of an animal, as such an offering.

In the first case, LoDagaa offerings are similar to those made 
Sacrifice among the LoDagaa and elsewhere : a comparative comment 15

to a living person, though the food may be prepared or unprepared and the drink may be beer or water. For example, offerings of first fruits usually consist of a head of guinea-corn, whereas offerings to the ancestors are always cooked; so are most presentations of foodstuffs. Animals are never killed as offerings to living persons, with the exception of a guinea fowl to a lover and a chicken to a succesful initiate at the Bagre ceremony ; both these birds are killed by heating and blood does not flow. But not all offerings, certainly not all formal killings of animals, even those involving the shedding of blood (which is verbally equivalent to homicide), are in fact offerings to altars, part of the system of man-god communication. Among the LoDagaa (as among the Gourmantché, according to Cartry), one can see an implicit distinction between two types of immolation, which does not emerge at the lexico-graphical level.

These are :

i. offerings to a shrine, i.e. bagr in LoDagaa

ii. offerings made to the name of a dead individual (at a funeral). These latter also require formal treatment. The animals are not simply butchered, as at the market place. They are formally killed and formally divided. The schema for the division is similar to that used in offerings to the spiritual agencies; the meat is certainly not for sale, but shared among eligibles and participants.

The process of division raises another aspect of sacrifice as immolation, not as an offering to spiritual agencies, but as the ritual treatment of dangerous food. In the table below $I$ have tried to indicate how the consumption aspect of sacrifice relates to that of communication.

\section{The semantic field of "sacrifice" (actor term, LoDagaa)}

A. A formal act of communication, man to god

i. the context of offering (wider usage)

ii. the actual offering (narrower usage)

In this context "sacrifice" requires analysing in terms of other acts of man-god communication.
B. An act of immolation, the formal slaughter of animal, not necessarily as an offering to spiritual agencies. The analysis involves other acts of kizzing, of animals (wild as well as domestic), of men (in war and peace) and even sometimes of plants. 
It is important to realise that $A$ and $B$ do not stand in the relationship of whole to part ; different considerations intervene, which are rarely if ever stated in an explicit way.

In other words, it is necessary to see the killing of animals (including blood sacrifice) in the total context of social relations (including the cultural framework) before we can understand it. Because the killing of animals (I have argued) is, like the killing of humans, a very special and ambivalent affair : the sacrificer's knife, the bleatings of the animal, the outpouring of the blood, the division of the flesh. A living being has ceased to be. A life is lost. Blood is shed.

I am aware of certain similar ideas to do with cereals (the ki1ling of the Corn Goddess, so central to the work of Sir James Fraser), as wel1 as the more general notion that other living things have "souls", a form of life, which demands respect. But for the LoDagaa, it is only men and animals that have breath (nyovuor). More specifically, their death is accompanied by the outpouring of blood, just as the death of a human.

In my earlier account of the LoDagaa, I argued that all killings of both men and animals, all shedding of blood (zii tyizr) is doubleedged (1962 : 118). Even if a killing is honourable (as in war), the killer is always submitted to rites that are not only purificatory, but also, in a certain sense, condemnatory. And I suggested that the deliberate killing of livestock (which man is involved at one and the same time in keeping alive and in killing to eat) is nearly always carried out as a mystical act, an offering directed to some supernatural agency. "In one way, the shedding of the blood of the sacrifice upon the shrine subtly resolves the human dilemma ... : for not only is the responsability for the deed thrown on to superhuman powers but these agencies are even conceived of as being gratified by the act (1962 : 119).

Indeed something of the same situation exists with regard to wild animals. At least after killing a member of the category "black" animal, the hero has to go through a series of difficult rites; and the memory of the dead, harmful as well as glorious, lives on and may. require an altar to be erected, in this case to the beings of the wild. I suggested that this ambivalence may be connected not only with the 
rites a hunter and a homicide is made to endure, but with the division of the animal world into Black and White, as well as with what I shall call "protective totemism" in order to distinguish it from the more developed kind found in Australia involving a more or less systematic classification of the world.

It is important to consider not only to whom one makes offerings but also to whom one does not offer sacrifices, nor indeed make any attempt at communication, namely the High God. Here we are immediately brought into a comparative context because the LoDagaa themselves show the contrast between themselves and those who "pray to God" (pure naammin, 1it. greet God), that is, nembers of "world religions".

For the LoDagaa, one makes no offering to God, verbal or material, and especially no blood sacrifice. But they recognise that there are other societies in which blood sacrifice is rare, and in which any kind of material offering (to gods as distinct from priests) is less common a feature of spiritual relations. Sacrifice in the restricted sense is restricted to post-neolithic societies; it is a feature of agricultural religion. But West Africa societies in which blood sacrifice is rare include those where domestic animals are rare, those inhabiting the tsetse infested rain forest. Here rituals have largely to do without blood, and turn instead, as with the eto (mashed yam and palm oil) of Ashanti, to the bread and the wine. However, it is these very same societies that practised the shedding of human blood. It has been argued (not all that convincingly) that cannibalism occurs where there is a shortage of animal protein for human food. Is it also the case that human sacrifice occurs where there is a shortage of animal blood to offer to the gods? The argument cannot be taken too seriousIy. For in West Africa human sacrifice generally occurred in a celebratory context, i.e. at the death of the chief, when slaves and other humans would be killed to his name (or, more correctly, to accompany him), rather like the cows killed at the funeral of any distinguished man among the LoDagaa. Blood is shed but as a celebration rather than an offering.

Then there are those other societies in which sacrifice is rejected not for ecological but for ideaologica1 reasons (though clearly the ecological factors have ideaological counterparts). This situation existed within another Ghanaian society in which I worked, that of 
Gonja, a former kingdom in the savannah north of Ashanti. I say "within" Gonja because while Islam was in a certain sense the (or a) state religion, it was exclusively practised only by members of the Muslim estate; the ruling and commoner estates were more eclectic.

In Islam one does not offer blood sacrifices to God; and there is only one God. Even food offerings are not made. But food is given to the poor in the name of God, not only in the minor form of bean cakes to children among the Gonja but also in the more substantial form of food-kitchens and ecclesiastical property in those remarkable building clusters (markets, hospitals, schools and poor-houses) that surround the great mosque at Bursa, the old Ottoman capital, and other major mosques in the Middle East.

But meat is eaten, both on ceremonial and other occasions and therefore blood has to flow. At the festival of Dongi, each family tries to buy a sheep which is killed in a formal, "sacrificial" way, and the blood is mixed with earth, which is then made into round balls as a kind of offering to the ancestors. West African Islam generally takes cognizance of the ancestors as well as of the beings of the wild, the equivalent of the jinn. Even for ordinary secular purposes, the purposes of the market and the table where no thought of offering is present, the killing can only be done by a ritual officiant in a ritual way; the slaughter of the animal has to receive the blessing of God. So too in Judaism, with its whole elaboration of the notion of kosher.

In these religions, as in Christianity, there is communication to God but there are few offerings and no killing to God; there are no victims (except in the past). On the other hand, God is required to sanctify the killing of domestic animals.

In Christianity animal flesh was of course sometimes rejected through fasting, and replaced by the flesh of sea animals. This was so on Fridays, the day of Christ's crucifiction, as well as during the forty day Lenten fast that preceded Eastertide, the season of his death. But certain monastic orders, such as the Cistercian, founded in Burgundy in 1098, took the rejection a stage further and, aiming at a liberal observance of the rule of St. Benedict, banished meat from all their meals. Even after the relaxation of the ordinary diet in the fifteenth century, after which meat could be eaten, it was 
Sacrifice among the LoDagaa and elsewhere : a comparative comment 19

never cooked in the frater (i.e. refectory) kitchen but in a special flesh-frater or misericord (misericordia, i.e. compassion), where meat had long been available for monks undergoing bleeding.

The next "logical" stage is found is Hinduism. The Hindu religion fully accepts the idea of offerings to the gods, material as well as verbal, but it rejects not only blood offerings (sacrifice B) but all shedding of blood. Animals are killed and eaten only by "lower" castes, who are also the ones who drink alcohol and perform blood sacrifices. The stratification of belief and practice takes the following form :

$\begin{array}{llll} & \text { Diet } & \text { Drink } & \text { Worship } \\ \text { HIGH } & \text { Vegetarian } & \text { Tea } & \text { Offerings } \\ \text { LOW } & \text { Meat-eating } & \text { Alcohol } & \text { Sacrifice }\end{array}$

Among the higher castes, there is no need for the ritual killing of meat because there is no eating of meat, either secular or divine.

There is, then, a progressive decrease in blood offerings. In some world religions, which are also literate religions, there is not only avoidance of blood sacrifice, but rejection of meat altogether, at least in holy contexts or by holy men. In effect, an increase of asceticism, a rejection of the more concrete aspects of god-man communication, occured long before the recent process of secularisation that has been extensively explored by historians of religion. It was related to the stratification which is also, in crude terms, an evolution of religion.

$\begin{array}{llll}\text { HIGH } & \text { No slaughter } & \text { Rejection } & \text { Literate } \\ \text { LOW } & \text { Killing } & \text { Indulgence } & \text { Oral }\end{array}$

Even among the LoDagaa blood sacrifice has its internal critics ("its meat they'are after", someone recently commented to me), as well as its hidden contradictions ; men eat what is offered to the god, a contradiction clearly exposed to me by some actors. These are contradictions that do not exist in prayer nor do they exist in that new register which became so important in god-man communication, the written word. It is the written register that the priest now controls whereas previously he had controlled the slaughter of animals to the gods, though in Islam and in Israel he continued to control that 
slaughter of animals for men. Two things are happening here, both historically with the development of world religions, and now contemporaneously as Islam and Christianity confront the local religions of Africa. Firstly, there is the concentration on the High God, and the setting aside, to varying degrees, of lesser agencies. Secondly, there is the communication by prayer, with minimal emphasis placed on material offerings, especially on blood sacrifice. These tendencies occured when man and the gods became literate; at this time blood sacrifice began to fall into disuse. It was perhaps then that the contradiction involved in this form of communication became overexplicit, that faith became "spiritualized".

These are dangerous speculations, too reminiscent perhaps of the "evolutionary" thinking of our rejected ancestors, Tylor, Fraser, Robertson-Smith, to mention only the most acceptable. But in my view to understand"sacrifice" (and even at one level to understand LoDagaa sacrifice), we need to adopt a perspective that is at once diachronic and comparative.

To emphasize that my speculations are related to ethnographic reality at some points, I conclude by offering one specific account of a sacrifice, by the LoDagaa themselves, that reveals an interesting attitude.

The attitude is on $1 y$ one of the several possibilities in this society, as the code-making ethnographer only too easily forgets. But it shows that a certain recognition of contradiction does exist, a recognition that man-god communication has its humorous side (a friend bursts out laughing when this point is reached). The account comes from that very special source, the recitation of the Bagre, in which we find other comments upon the deceptiveness of sacrifice, for at one point, when man is attempting by means of sacrifice to communicate with God, whose role is emphasized throughout, a being of the wild intervenes in a cloud of dust and turns the chicken up the other way, giving man the incorrect answer (Goody 1972). In the present extract the theme is different, showing the humorous rather than the deceptive side of sacrifice. It is the Earth shrine that is speaking to God. 


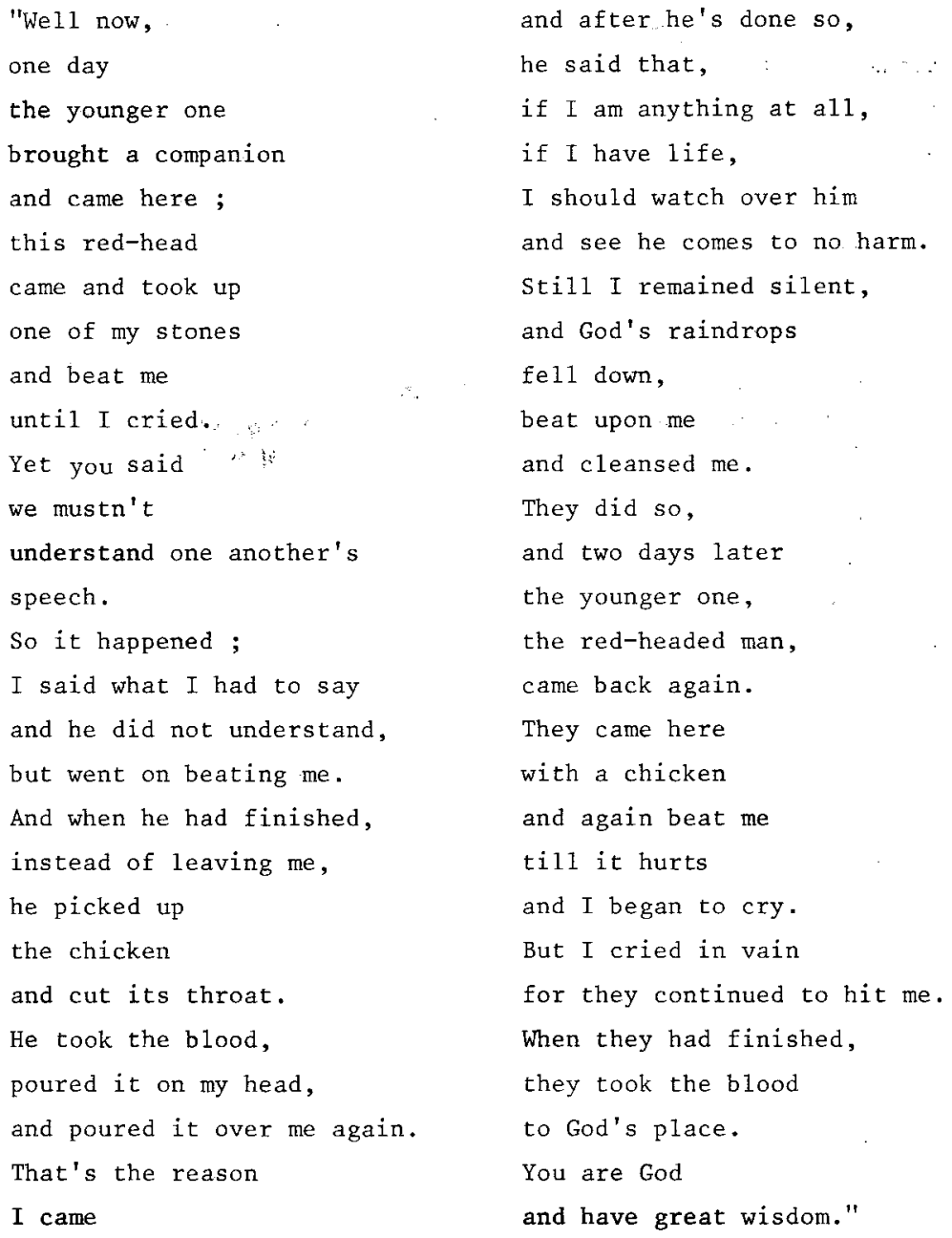

It is as well to leave the actors with the last word, a word that provides an unobtrusive commentary, an implicit questioning of the nature of the ways available to man to communicate with the gods. For a11 is not as it seems to the innocent enquirer. The LoDagaa too have their ironies and their scepticism, not simply about whether one diviner is a fraud, or whether a particular sacrifice is a waste of time. There is a more general scepticism about whether it is worth playing this game 
at all. We do it, the Bagre initiates are told of one of the central institutions of LoDagaa culture, because the ancestors told us to. But in fact we've strayed from the path of God, the path of knowledge. It is this attitude that makes conversion to a non-sacrificial religion an ever-present possibility.

\section{References}

CARTRY, M., 1976 : Le statut de l'animal dans le système sacrificiel des Gourmantché (Haute Volta), première partie, Systèmes de pensée en Afrique noire, cahier 2, Le sacrifice I, pp. 141-175.

FORTES, M., 1949 : The Web of Kinship Among the TalZensi, London. GOODY, J., 1962 : Death, Property and the Ancestors, Stanford University Press.

1972 : The Myth of the Bagre, Oxford, C1arendon Press. 